\title{
Article
}

\section{Territorial Extension of the EU Environmental Law and Its Impacts on Emerging Industrial Economies: A Taiwan Case}

\author{
Hsing-Hao $\mathrm{Wu}^{*}$
}

This article explores the territorial extension of the EU environmental law and how the EU uses its market powers to become global regulatory initiatives in the context of environmental protection. The legitimacy and practical influence of the global reach of the EU environmental law is first to be discussed. Taiwan, as a significant trade partner to the $E U$ and also a critical exporting-oriented industrial entity in the world, has been heavily influenced by the EU environmental law development for the sake of gaining market access to the EU. In this regard, this article provides an overview of the EU environmental law. This article will provide a case study on the territorial effects of the EU environmental law on Taiwan and the responsive actions taken by the government and industries in Taiwan. This article recognizes the importance of the EU to achieve legitimate global values in the context of global environmental protection.

Keywords: Brussels Effects, Territorial Extension, EU Aviation Directive, Product-based Environmental Regulation, Market Access

* Associate Professor of Department of Financial and Economic Law, National University of Kaohsiung (NUK), Taiwan; Director, International Relation Research Center, NUK. S.J.D. (Indiana Univ.-Blommington). ORCID: https://orcid.org/0000-0001-7593-3655. The author can be reached at: hsiwu@nuk.edu.tw/Address: 700, Kaohsiung University Rd., Nanzih District, Kaohsiung 811, Taiwan.

All the websites cited in this article were last visited on August 4, 2020. 


\section{INTRODUCTION}

The territorial extension of the EU law is commonly referred to as "Brussels Effect." It extends legal effects and accountability of the EU law to non-EU parties outside the EU borders through market mechanisms. In other words, the EU uses its market power, such as imposing market access requirements to extend the applicability of relatively stringent regulatory rules or standards over conduct that takes place outside the EU border. Professor Scott defines the territorial extension as "the application of a measure that is triggered by a territorial connection, but in applying the measure, the regulator is required, as a matter of law, to take into account conduct or circumstances abroad." Supporters for the Brussels Effect argue that territorial extension in the EU law is effective in strengthening international norms or implementing international consensus-based commitments, such as environmental protection or fair competition that results in the "race to the top" phenomenon at the global scale. ${ }^{2}$ In the meantime, the extraterritorial effects of the EU law may be criticized or contended with for their inconsistency with international legal norms or principles, or they may possibly be used as "disguised forms of trade protectionism." ${ }^{3}$

Although the EU has been actively using its market powers to compel its trade partner to adjust their product design or business practice in compliance with the EU regulation or product standards, the long arm effects across national boarder of domestic law is the first to be adopted by the US. The US had imposed unilateral trade measures based on the Marine Mammal Protection Act (MMPA) to ban or restrict shrimp exports from certain countries for the sake of accidental capture of sea turtles as a result of commercial fisheries. ${ }^{4}$ The unilateral trade measures were also imposed on tuna products exporting from certain countries, due to their unsustainable fishery practices resulting accidental capture of dolphins.

The US required that shrimp and tuna products intended for export to the American markets wishing to lift the ban on importation would adjust their commercial fishery practices to prevent the accidental killing of other marine mammals. The restrictive trade measures, however, had been contested by the US's trade partners in the WTO Dispute Settlement Understanding (DSU), alleging that trade measures focusing on the production process, rather than products themselves, should not be justified under the exceptions provided by the WTO/ 
GATT Agreement. The Panel initially ruled in favor of contending parties that the US should not discriminate between contending Member countries by providing a different level of financial and technical assistance on mammal protective fishery development. The WTO DSU later ruled in favor of the US, stating that the US was justified under GATT because the US no longer discriminated in the application of their exception under Article XX(g).

In addition to marine mammal protection, the US has also regularly used its dominant market powers to compel its trade partners towards domestic legal reform and the enhancement of legal enforcement in the context of intellectual property rights protection, the modifications of subsidy policy, or the removal of unfair trade policies. This so-called long arms-stretching effect of the US law has been criticized for lacking prior international consultation to the enactment of domestic legislation that has exterritorial effects, some of which aim at protecting the US trade interests rather than achieving public interest objectives as we have seen in the Shrimp/Turtle and Tuna/Dolphin cases. ${ }^{6}$

The Brussels Effects, on the other hand, do not necessarily protect the EU's trade interests but rather to promote public interests such as environmental or human rights protection at the global scale. Here, most of them have already reached international consensus or even international norms in place or at least resulting influence toward international legal development. ${ }^{7}$ The territorial extension of the EU law may lead to the globalization of rules and standards to reach internationally agreed policy objectives. It thus adopts more solid and relatively stricter rules or standards than those imposed by international organizations or non-EU states. In this regard, this "race to the top" phenomenon as a result of the Brussels Effects received some criticisms for lacking strong support from international organizations, and the unilateral exercise of the EU's regulatory powers outside its borders would seriously affect developing countries due to their lack of competent regulatory and institutional capacity to adapt to the EU law. ${ }^{8}$ For instance, the territorial extension of the EU law in the context of fishery and timber regulation has resulted in enormous adverse economic impacts to those countries that heavily depend on fishery and timber exports in some Southeast Asia countries such as Thailand, Malaysia, Indonesia, and Vietnam. ${ }^{9}$

For the sake of preserving a sustainable fishery stock and a healthy ocean environment, the effective enforcement of effective regulations that aims to combat 
illegal, unreported, and unregulated (IUU) fishing at a global scale plays a vital role in reaching the objective. ${ }^{10}$ Recognizing the importance of tackling IUU issues, the EU, as the most significant market for fishery products in the world, thus initiates the regulation to prevent, deter, and eliminate IUU fishing (EU IUU Regulation). The EU IUU regulation requires that only marine fisheries products to be certified under the EU catch certification scheme by the competent flag state or exporting state can be imported to or exported from the EU. ${ }^{11}$ In other words, those countries lacking vigorous enforcement on IUU fishing would be banned or restricted for their fishery products exporting to the EU market. ${ }^{12}$ The IUU Regulation applies to not only the EU operators catching fish outside the EU borders under any flags, but also the non-EU member exporting states. In implementing the IUU Regulation, the EU has initiated the IUU vessel list annually that categorizes targeted states to impose a different degree of trade restriction measures on their exporting fishery products. The EU evaluates the progress made by the targeted states in terms of illegal fishing enforcement in compliance with the IUU Regulation to adjust the vessel list. ${ }^{13}$

The main objective of the IUU Regulation is not to protect its market power because the rule applies to the EU operator under any flags and in and out of the EU market. ${ }^{14}$ Instead, the implementation of the IUU Regulation injects the Brussels Effects, ensuring that the provisions of the international agreement, such as the UN Convention on the Law of the Sea 1982 and the UN Fish Stocks Agreement 1995 developed by the FAO, have been fully enforced. The EU also initiated the regulation prohibiting the EU economic operators from purchasing fish or fishery products exporting from countries allowing unsustainable fishing. ${ }^{15}$ In short, the IUU Regulation has served as the global catalyst for achieving environmental sustainability and resource conservation in terms of the fishery sector, not limited to the EU territorial waters.

Another example of using the Brussels Effects to protect the environment and natural resources conservation is the development of the EU Timber Regulation (EUTR) after 2010. The illegal timer has resulted in enormous environmental, social, and economic adverse effects. The exploitation of forests as a result of unsustainable harvesting practices shall be addressed. It is thus vital for those states with productive forest resources to enhance their domestic forestry protection laws in order to comply with EUTR requirements. Trading these timer 
products to the EU market are required by the EU laws to exercise the principle of "due diligence." The key features of due diligence are comprised of the following three concepts:

Information: The operator must have access to information concerning timber and timber products, such as the country of harvest, species, quantity, suppliers, and their compliance with national legislation.

Risk assessment: Traders are required to assess the risks of illegal timber within their supply chains.

Risk mitigation: When the risk of illegal timber is found, suppliers are required to provide additional information and verification to mitigate the risks. ${ }^{16}$

\section{The EU EnVironmental LaW With Territorial EXTENSION EFFECTS}

\section{A. The EU Aviation Directive}

The EU is arguably the most aggressive regulatory power as a supranational entity in implementing the GHG emission reduction programs as market-based mechanisms implementing the GHG emission reduction targets set by the United Nations Framework Convention on Climate Change (UNFCCC) and the Kyoto Protocol. The greenhouse gas emission trading scheme (ETS) is deemed as one of the most cost-effective mechanisms for industry sectors seeking economic and technologically feasible solutions to achieve their GHG emission reduction objectives required by either domestic law or voluntary programs without compromising their economic competition. The EU has begun to establish the GHG Emission Trading System (ETS) covering approximately fifty percent of the EU's GHG emissions from listed industries since 2003. ETS is a carbon trading market which initially set the GHG emission allowance within the EU for power plants and energy-intensive industries and later was extended to aviation activities arriving at or departing from the EU airports. In 2009, the EU adopted the EU Directive 2008/101/EC (Aviation Directive), which sets carbon emission allowances and application of the EU ETS to the global aviation sector. This EU Directive also met with resistance from other countries, including Russia and the US. Although the European Court of Justice (ECJ) finally decided the directive as 
being valid, ${ }^{17}$ it was finally suspended by the EU under external pressure in 2012. In October 2016, the climate change negotiations at the 39th Conference of the International Civil Aviation Organization (ICAO) held in Montreal, Canada, were fruitful. Here, the following two relevant documents constituted the first emission reduction market mechanism for the global industry: (1) the Consolidated Statement of Continuing ICAO Policies and Practices Related to Environmental ProtectionClimate Change; and (2) the Consolidated Statement of Continuing ICAO Policies and Practices Related to Environmental Protection-Global Market-Based Measure (MBM) Scheme. ${ }^{18}$

The EU's Aviation Directive requires airline operators to report their aviation carbon emission arriving at or departing from the EU in order to account for their carbon emissions and submit a sufficient number of the EU emission allowances (EUAs). An EUA is the emission limit, allowing emitters flexibility in meeting the limits through the buying, selling, and trading of the EUA at the carbon emission market or among other emitters. ${ }^{19}$ The obligation thus presents the extraterritorial effects because the Aviation Directive applies the EU ETS to non-EU air transport operators and all segments of the entire flight, including those taking place outside the EU. ${ }^{20}$ The adoption of the Aviation Directive may not only have a positive impact on shaping the international standards or protecting the EU's policy objective, but also encourage other states to unilateral actions for protecting their interests and leading to trade disputes. The Aviation Directive thus imposes significant impacts on non-EU airline operators due to the lack of domestic legislation and policy establishing ETS or the mandatory GHG emission reduction targets for the aviation industry. The considerable opposition came from the US, China, Russia, and India in particular, challenging the Aviation Directive's legitimacy for not complying with international law. ${ }^{21}$

The Air Transport Association of America (ATA) joined with many US and Canadian airlines, initiated a suit to the ECJ challenging the legality of the EU's unilateral actions for the inclusion of non-EU aviation activities to the EU ETS. ${ }^{22}$ On December 21, 2011, the ECJ rendered its ruling upholding the Aviation Directive on the grounds that neither customary international laws, nor existing treaties barred the EU from applying its Directive to third country aircraft operators or those operating outside of its territory. ${ }^{23}$ Recognizing the stance taken by the ECJ concerning the legality of Aviation Directive, Taiwan shows its willingness to 
assume responsibility commensurate with its development stage and ability. In this regard, it has been actively controlling and reducing its aviation energy consumption and emissions, taking an active part in relevant international cooperation efforts. Additionally, Taiwan started a pilot carbon trading market in 2011 that was officially launched in 2014. Currently, two major Taiwanese-based airlines seek to participate in domestic and EU carbon trading markets. ${ }^{24}$

Compared with product-based environmental regulation providing relatively limited exemptions to products exported to the EU, the Aviation Directive provides a feasible mechanism allowing the third country to apply for exemptions from the Aviation Directive requirements. As Professor Scott observes and argues, the EU law's territorial effects reflect both the provisionally and flexibility features in comparison with unilateral measures adopted by other states such as the US. ${ }^{25}$

The Aviation Directive is a compelling example that the EU is willing to consult with individual states, continue to work with international partners, and amend the relevant EU instruments. Specifically, the Aviation Directive provides an exemption to flights departing from third- countries when the third country in question has adopted relevant laws and regulations aiming to reduce the GHG emission generated from these flights. The EU is thus required to review the legal framework for the third country in question. Moreover, the EU is required to take into account amending the Aviation Directive if an international agreement to reduce aviation emission is to be reached. ${ }^{26}$

\section{B. EU Product-based Environmental Law and Regulation}

\section{Chemicals and Toxic Substance Management: REACH}

The primary chemical legal framework for chemical management in EU is the Regulation on Registration, Evaluation, Authorization, and Restriction of Chemicals (REACH), which came into effect in June $2007 .^{27}$ The main objective of REACH is to provide a high level of protection for human health and the environment from chemical products circulated in the market. The main feature for the implementation of REACH is to impose great legal responsibility for manufacturers, traders, and retailers to accurately assess and control the risks posed by chemicals or certain substances to human health and the environment and to provide appropriate products' safety information for the European Chemicals Agency (ECHA) and consumers. REACH seeks to enhance risk communication concerning chemicals 
among manufacturing companies, waste disposal operators, and retailers within the entire supply chain by developing reporting mechanisms and tools to assist companies and public authorities in fulfilling their legal obligations. ${ }^{28}$

\section{Registration}

All manufacturers and importers of chemicals are required to identify and manage risks associated with the substances they produced and circulate in the market. Companies that manufactured or imported listed substances for more than one tonne in quantities per year shall submit related product information to the ECHA. ${ }^{29}$ Notably, the unique registration regime is applied to some products containing regulated substances such as automobiles and electronic components. However, REACH provides registration requirements exemptions for certain substances under some circumstances.

\section{Evaluation}

The ECHA is authorized to evaluate whether the registration dossiers are complying with the REACH requirements. Notably, the ECHA shall evaluate testing proposals to ensure that the assessment of the chemical substances will not result in unnecessary testing and adequate information is provided. ${ }^{31}$ The ECHA is also authorized by REACH to select certain substances for a broader substance evaluation when deemed necessary. ${ }^{32}$

\section{Authorization}

The European Commission makes the decisions for whether the substances subject to authorization under REACH are authorized to circulate within the EU market by taking into account that the risks from substances of very high concern (SVHCs) are appropriately managed, and up-to-date alternative substances or technologies replace those SVHCs. ${ }^{33}$ The commission grants authorizations by consultation with the Committee for Risk Assessment (RAC) and the Committee for Socio-economic Analysis (SEAC) of the ECHA, considering whether the risks from the use of the substance are adequately controlled, or the socio-economic benefits outweigh the risks to human health or the environment. ${ }^{34}$ Once the listed substances subject to authorization fails to obtain authorization from the EU Commission within the time frame required by the Directive, these substances are 
no longer permissible to be used or circulated in the EU markets. ${ }^{35}$

\section{Restrictions}

The EU Member States or the European Commission are authorized to impose restrictions on the manufacture, use, or placing on the market of certain substances posing unacceptable risks to human health or the environment. Restrictions are designed to manage unacceptable risks that are not addressed either by other REACH processes, or by other EU legislation. Restrictions are listed in Annex XVII to the REACH Regulation. ${ }^{36}$

Although environmentalists have endorsed the implementation of REACH for managing risks to human health or the environment, the implementation of $\mathrm{REACH}$ resulted in significant economic impacts on a wide range of non-EU member companies seeking to import or to use chemicals or products containing the listed substances under REACH in the EU market without exemptions. ${ }^{37}$ The implementation of REACH thus results in significant economic impacts to nonEU-based chemical or manufacturing industries, including Taiwan, for complying with the relevant legal obligations in a short-term period after REACH went into effect while differences between domestic law and REACH exist. ${ }^{38}$ Some argue that the implementation of REACH to all related chemical or product imports to the EU may create an unnecessary administrative burden and technical barriers to market access. ${ }^{39}$

\section{Restriction of Use of Certain Hazardous Substances Directive 2002/95/EC (RoHS)} In response to the growing health concerns for the products containing hazardous materials, the EU has adopted a regulatory approach to preventing or restricting the use of heavy mental substances contained in the product marketing since the implementation of the Directive in 2006. RoHS imposes legal obligations for manufacturers and importers of electrical and electronic equipment to ensure that their products shall not contain certain hazardous substances required by the RoHS, namely lead, mercury, cadmium, hexavalent chromium, polybrominated biphenyls ethers (PBB) and polybrominated diphenyl ethers (PBDE). ${ }^{40}$ RoHS's prohibition requirements also apply to imported electrical and electronic equipment, which result in enormous economic impacts on Taiwan's electronic equipment and components manufacturing industry. Notably, over 43 percent of Taiwan exports 
in 2018 are electrical machinery and equipment (HS85). ${ }^{41}$ RoHS does, however, only provide limited exceptions to the prohibitions for specific applications. Due to EU clients' demands, the compliance of RoHS has resulted in significant implications to EE product manufacturers outside the EU in terms of supply chain management, raw materials selection and testing, and, most importantly, the rise of manufacturing cost. ${ }^{42}$

\section{The EU Ecolabel}

Recognizing the importance of reducing environmental impacts as a result of production, the EU first initiated the Ecolabel award scheme regulation that aims at promoting producers to reduce environmental impacts throughout the products' entire lifecycles since 1992. The EU Ecolabel scheme was modified in 2000 and 2010 to encourage producers to meet specific product group criteria and high environmental standards to obtain the eco-logo. ${ }^{43}$ The Ecolabel is a voluntary program that aims at implementing the EU sustainable production and consumption policy by encouraging producers to reduce environmental impacts, such as $\mathrm{CO} 2$ emission and natural resource consumption, in the distribution and production process. ${ }^{44}$

Furthermore, the EU Ecolabel promotes the circular economy concept by encouraging producers to design eco-friendly products that are durable and easy to reuse or recycle. ${ }^{45}$ Given that the EU Ecolabel operates following ISO 14024 (Type I Label), many companies, including non-EU-based companies, are willing to seek Ecolabel criteria guidance on environment-friendly design and best practices because public procurement requirements and consumers preference to purchase products with the Ecolabel in recent years. ${ }^{46}$

\section{The EU's Energy Use and Eco-Design Directive}

Recognizing that environmental harms caused throughout the entire product lifecycle could be prevented or reduced at product's design stage, the EU has adopted the Eco-design Directive authorizing the European Commission to adopt appropriate measures requiring manufacturers to comply with a product's ecodesign requirements. ${ }^{47}$ The EU first initiated the Energy Using Products (EUP) Directive 2005/32/EC that establishes the eco-design and performance standards for specific energy-using products in July $2005{ }^{48}$ The EUP Directive empowers the European Commission to adopt eco-design requirements for products placed 
in the EU market. ${ }^{49}$ The EUP Directive regulates a wide range of energy-using products placed on the EU market and imported goods, including parts intended to be incorporated into products with environment performance and product design requirements presenting their potentials to reduce environmental impacts without high costs. ${ }^{50}$

As regards the EUP Directive, the European Commission is required to consider the entire lifecycle of the product and also take into account the consumption of raw materials, energy, and water for manufacturing such products. ${ }^{51}$ The scope of this measure is limited in the sense that it only covers products placed on the EU market having an impact on energy consumption during use. Moreover, for a product of this kind to be subject to implementing measures, it must be demonstrated to have a significant environmental impact within the EU. ${ }^{52}$ From the environmental perspectives, the EUP directive requires a product's eco-design measures to ensure that there are no harmful effects on health, safety, and the environment as a result of placing energy-using products in the EU markets. ${ }^{53}$ For the sake of producing easy recovery and recycle energy-using products, according to the EUP directive, product design standards shall ensure that easily recyclable materials, easy access to valuable and other recycling components and materials, and easy access to those hazardous materials and components can be used for future designed products. ${ }^{54}$

\section{The EU Waste Management Law}

The underlining policies of the EU waste management framework are based on the 3Rs principles (Reduce, Reuse, and Recycle) and cycle-loop economy concepts. In implementing these guiding principles to handle electronic waste properly, the EU developed two waste management directives, namely the Waste Electric and Electronic Equipment (WEEE Directive) ${ }^{55}$ and the Restriction of the Use of Certain Hazardous Substances in Electrical and Electronic Equipment (RoHS Directive). ${ }^{56}$ Both aims to reduce the volumes of electronic waste, increase the reuse and recycle rate, and further, to better control the risks to human health and environment by incorporating the product's eco-design requirements and "extended producer responsibility" principles to a wide range of electronic waste including household appliances, ICT products, consumer electronics, and other electronic waste. ${ }^{57}$ The EU has effectively set new global product standards that are expected to drive design changes for a variety of products intending to access to the $\mathrm{EU}$ 
market, regardless of where they are manufactured and sold. ${ }^{58}$

\section{WEEE Directive}

As mentioned earlier, the WEEE Directive was first introduced in the EU in February 2003, and the latest amendment of 2012/19/EU replaced the Directive. The main objective of the WEEE Directive is to improve the collection, reuse, and recycling of e-waste and reduce the disposal of e-waste. To achieve the objective, the WEEE Directive adopts the "Producer Extended Responsibility" concept, which imbues all participants of the entire supply chain, including manufacturers, importers, and scaled retailers with the strict legal responsibility to collect, reuse and recycle used WEEE. ${ }^{59}$ In implementing this "Producer Extended Responsibility" scheme, WEEE allows private households to return used electrical and electronic equipment to retailers selling the equivalent type of discarded equipment. ${ }^{60}$ The retailers are obligated by WEEE to collect these used electrical and electronic equipment without charging any processing fee for small WEEE (less than $25 \mathrm{~cm}$ ). ${ }^{61}$ WEEE also allows producers to develop their own "take-back" system. ${ }^{6}$

It is also notable that the WEEE Directive develops an EU approved EEE designated product marking and registration scheme and establishes a fixed collection and recycling rate for WEEE. Moreover, WEEE requires Member States to encourage the design and production of EEE to facilitate dismantling and recovery, as well as the ease of reuse and recycling of WEEE and components and materials. ${ }^{63}$

WEEE does, however, only provide limited exceptions to certain products such as security equipment, arms, munitions and war materials from the Member States. None of the exemptions will be given to all imported electrical and electronic equipment, regardless of the application purposes under the WEEE.

\section{The EU's Latest Amendment to Waste Legislation: 2018/851/EU}

The most recent amendment of the EU waste framework directive was entered into force in July 2018. The directive aims at enhancing the progress of achieving the reuse and recycle of waste targets set in 2008/98/EC and initiating the Europe 2020 Strategy facilitating the ambitious policy goal of a circular economy. ${ }^{64}$ For the sake of enhancing traceability of proper handling of hazardous waste and improving the monitoring of waste flows within the EU, the directive adopts an 
electronic registries scheme requiring producers to provide hazardous substances containment information available to waste disposal operators and consumers by January $2020 .^{65}$ Specifically, the new law strengthens the obligations for producers to communicate the entire supply chain participants and notify ECHA concerning the Candidate List substances in articles. ${ }^{66}$ Thus, a new database is to be established for gathering information submitted by companies producing, importing, or selling articles containing Candidate List substances. The database is to first impose record-keeping obligations for producers to trace the waste flow and further to allow consumers to make their preference for safer products. It also tries to increase pressure for producers to substitute alternative substances for toxic substances in question. The companies need to submit this information by the end of $2020 .^{67}$

The exact impacts of the latest amendment of the EU waste management legislation to the exporting industry are still unknown. However, Taiwan's manufacturing companies have started to evaluate the risks for submitting the hazardous waste information to ECHA and the disclosure of this information to consumers. Many business owners in Taiwan, especially for Small and Medium Size Enterprises (SMEs) are afraid that disclosure of articles containing Candidate List substances subject to reporting requirements may result in trade secret leaking to their competitors learning from experience in Taiwan. ${ }^{68}$

\section{Territorial Extension Effects of the EU ENVIRONMENTAL LAW TO TAIWAN}

\section{A. The EU-Taiwan's Economic Ties}

The relationship between the EU and Taiwan has been stable and healthy in the areas of culture, academic exchange, tourism, and, most importantly, the trade and business. Taiwan is the EU's sixth-largest trading partner in Asia. The EU is meanwhile the fifth-largest trading partner to Taiwan after China, ASEAN, the US, and Japan. The bilateral trade and business relationship have been reinforced in recent. In 2019, Taiwan became the EU's fifteen trading partner in the world. ${ }^{69}$ The bilateral trade in goods amount was increased by 9.8 percent, which reached the historical high of Euro 50.2bn. The major trade-in goods between the EU 
and Taiwan are information and communications technology (ICT) products, machinery, transport equipment, and chemicals. ${ }^{70}$ It is even more surprising that the EU has been the most significant foreign direct investment (FDI) source for Taiwan for years. Taiwan has proven itself as one of the leading suppliers of electronic components such as computer memory chips and semiconductors in the context of global ICT products supply chain. Evidently, electronic equipment accounts for 43 percent of Taiwan's total export to the world. ${ }^{71}$ Moreover, 82 percent of the EU's FDI to Taiwan flows into the category of electronic parts and components manufacturing. ${ }^{72}$

\section{B. Taiwan's Legal and Industrial Development}

Traditionally, Taiwan's legal framework has been heavily influenced by the development of the EU law, because Taiwan adopts a civil law system instead of common law, and many legal scholars and practitioners studied in European countries such as Germany, Austria, and France. Also, Taiwan's economic growth has heavily relied on foreign trade. For complying with primary exporting market's productbased regulations, the EU's legal development concerning trade and international business has become a major driving force for Taiwan to change a compatible legal environment, or industrial policy to comply with the EU's product-based environmental laws. ${ }^{73}$ As Professor Scott indicates, the territorial extension of the EU law has reflected general orientation characteristics that lead to establishing or refining the international standards generally recognized and enforced by major economic powers. $^{74}$

The influence of the EU laws on Taiwan's legal system is also driven by Taiwan's policy, seeking to reintegrate into the international society necessary to incorporate the EU's standards or legal principles into Taiwan's domestic legal framework. Legal reform driven by foreign laws is a way of gaining international support and shows to the world that Taiwan is capable and willing to comply with international norms. 


\section{The Territorial Extension Effects of the EU's Product-Based EnVIronmental LaW To TaIWAN: Legal AND INDUSTRIAL ResPonses}

\section{A. Territorial Extension Effects of EU's Product-based Environmental}

\section{Law to Taiwan}

The increasing economic and trade relations between the EU and Taiwan have indeed created more significant impacts on the industry in Taiwan as a result of the territorial reach of the EU laws. Notably, the uncertain global trading environment may result in increasing exports of Taiwan to the EU partly because exports of Taiwan-manufactured electronic parts and components to China would be significantly affected by the recent trade war between the US and China. In the long term, Chinese ICT producers are expected to expand trade opportunities to the EU instead of the US market. ${ }^{76}$ China and Hong Kong are the most significant export markets that account for nearly 40 percent of Taiwan's net exports. By product group category, electronic equipment and machinery account for over 70 percent of total Taiwan's exports to China and Hong Kong. ${ }^{77}$ As mentioned earlier, ICT products such as integrated circuits and electronic components are Taiwan's most famous export commodity, accounting for more than half of Taiwan's exports to the EU $(56.0 \%$ or Euro $11.2 \mathrm{bn}) .^{78}$ In this regard, Taiwan's electronic parts and components suppliers for China- and Hong Kong-based ICT producers will be more pressured to comply with the EU law for expanding future trade opportunities between China and the EU. It is thus critical for Taiwan's government as well as its manufacturing industry and business service providers to study in-depth and seek product design and market strategies that are responsive to the potential expansion of trade opportunities and the enhancement of economic ties between Taiwan and the EU. ${ }^{79}$

\section{B. Taiwan's Legal and Industrial Response}

The full compliance to the EU's product-based environmental regulation, including product design requirements, chemical and WEEE management, shall be promoted at both the government and industrial level. Taiwanese manufacturing companies, especially the EEE manufacturing industry, is at the top of the targeted industry sector influenced by the EU product-based environmental law. Those 
EEE manufacturing companies in Taiwan that intend to import and sell their products to the EU find it too costly to develop different products meeting different markets in terms of product design and manufacturing process. ${ }^{80}$ Therefore, the compliance on the most strict product-based standards in the world, such as the EU regulation, may meet their needs for a "One-Fits-for All" objective. For those producers in Taiwan acting as key suppliers in global supply chain are thus willing to redesign their products, taking into account the entire life cycle of their products meeting the EU approved general testing practice in order to comply with WEEE and RoHS requirements and obtain the EU approved product-marking and market access approval. $^{81}$

From the author's observation, the government and industry in Taiwan adopt a parallel approach in response to EU product-based environmental law development. A significant portion of manufacturing companies exporting goods to the EU is composed of relatively SMEs within the supply chain. These companies often lack legal compliance departments, scaled R\&D teams and international certified testing centers or labs that are capable of monitoring the latest legal development in their exporting market and adjusting to the context of product's design in order to promptly comply with the EU laws. As a result, Taiwanese manufacturing companies are compelled to seek external assistance. As an automated response to the EU REACH Regulation and RoHS Directive, for instance, Taiwanese manufacturing companies would usually seek for the service provided by the EU approved lab or testing organization such as the SGS or the Taiwan Electronic Testing Center. The intensive testing requirements for each substance used for exporting products have become a financial burden for SMEs. Some SMEs even thus give up trade opportunities with the EU market due to the financial burden and the lack of technical support to comply with the EU law. ${ }^{82}$

The response to the EU's legal development from a government perspective is relatively slow and uncoordinated. For example, regulatory power to all kinds of waste is vested to the Taiwan Environmental Protection Agency (TEPA). At the same time, the Ministry of Economic Affairs is responsible for assisting the industry in upgrading or maintaining its competitiveness in the international market. The response from the Taiwanese government to the EU product-based environmental regulation is thus slow and fragmented due to the lack of a coordinated mechanism in responding to the latest international standards. 
In practice, many legislators are aggressively pushing for legal change if the EU has developed a product-based law that reflects environmental concerns. TEPA is thus compelled to develop a legal proposal deemed as a positive move towads integrating international waste management trends such as circular economy into Taiwan's existing legal framework since 2005. The legal proposal incorporates the guiding principles such as 3Rs principles and circular economy, which have been incorporated in the EU waste legislation. ${ }^{83}$ The direct transplantation of the EU regulatory measures into Taiwan's legal framework has been questioned for the enormous economic impacts on the industry as a result of the legal amendment. The legal proposal has received considerable opposition from the industry, legislators supporting the industry's voices, and even the Ministry of Economic Affairs. Lacking a coordinated mechanism between the TEPA and Ministry of Economic Affairs to enhance regulatory compliance and technical assistance to the targeted industry eventually results in longstanding mistrust and the conflict of interests between the TEPA and Ministry of Economic Affairs. ${ }^{84}$

Finally, this top-down approach adopted by the waste management regulatory authority without close consultation and coordinated efforts to provide government support for industry aiming at upgrading technology or product design will eventually fail to in establishing an ambitious waste management legal framework based on 3Rs principles and the circular economy. ${ }^{85}$

Another example illustrated here is the industrial and government response to the REACH Directive in Taiwan. TEPA is the regulatory authority for managing chemical flow in Taiwan's market. In response to the REACH Directive, TEPA has worked with ECHA and the OECD to access and obtain the legal development information through an information exchange platform. TEPA has thus provided the gathered information concerning the EU REACH requirements to the local industries to encourage them to seek safer use and recommended alternatives to Substances of Very High Concern (SVHCs) in compliance with REACH obligations. ${ }^{86}$ TEPA's response to the EU law development led to the proposal to amend laws or regulations through the transplantation of more advanced economies. Moreover, in December 2015, the Taiwan Bureau of Standards Metrology and Inspection (TBSMI) officially included lead, mercury, cadmium, hexavalent chromium, polybrominated biphenyls ethers (PBB), and polybrominated diphenyl ethers (PBDE) regulated by RoHS as regulated substances in Taiwan's product 
inspection and registration system. The TBSMI requires products containing these six hazardous substances to provide information by labeling encompassed ICT products, light, and electronic machinery. ${ }^{87}$

\section{Taiwan's Legal and Industrial Response to the EU's Climate Change Law}

Responding to the EU Aviation Directive, two Taiwanese air transport operators, China Airlines and EVA Air, along with the Taiwan Civil Aeronautics Administration (TCAA), surprisingly declared that they would comply with any requirement under the EU Aviation Directive. ${ }^{88}$ China Airlines and EVA Air estimated that approximately Euro 10 million per year should be paid by these two major carriers to purchase aviation emissions allowance from carbon trading system. ${ }^{89}$ In October 2016, ICAO developed a global market-based measure aimed at stabilizing global aviation GHG emissions at 2020 level. ${ }^{90}$ It is also notable that Air transport operators such as the Eva Airline declared that they would comply with ICAO carbon offset and reduction measures by achieving the Carbon Neutral Growth by 2020 objective and increasing fuel efficiency by 1.5 percent a year. ${ }^{91}$

The direct transplantation of the EU's product-based environmental law into Taiwan's waste and chemical management legal framework has changed the law that Taiwan may impose in order to induce pressure on certain industries, such as the electronic equipment manufacturing sector, to produce more sustainable products, which, in turn, would sustain Taiwan's global competitiveness. ${ }^{92}$ In practice, the manufacturing industry in Taiwan seeks guidance and solutions from many EU consulting firms for product standards. Although there are significant cost implications for Taiwanese enterprise, acting as key suppliers to global supply chain and adherence to multinational clients' demands to export products to the EU market eventually compel Taiwanese firms to address these challenges by taking into account products' life cycle assessments in order to comply with RoHS requirements. It is thus critical for the Taiwanese government to establish crossagency task forces to provide legal, financial and economic assistance for local companies or industrial associations to develop low-toxic and recyclable materials contained within the products in order to lawfully comply with international standards, including those of the EU product-based regulation. ${ }^{93}$ 


\section{Conclusion ANd Suggestions}

The EU has used its regulatory power not only to reshape the EU's economies to incorporate environmental and health concerns, but also to lead the development of sustainable global product standards by using its market power wisely. Moreover, the EU law concerning chemical, waste and GHG reduction measures are expected to achieve behavior changes for producers, while designing the product, regardless of where they are manufactured and sold. ${ }^{94}$ By conditioning market access for a wide range of products on the EU's product-based environmental requirements, for instance, Taiwan is compelled to implement legal and industrial adaptation measures in order to maintain its global competitiveness in the field of the electronic manufacturing components supply chain, thereby resulting in high economic negative impacts as well as difficulties for the institutional modernization process. $^{95}$

However, the EU product-based environmental law will become a leading force for developing international standards, ensuring that environmental and health concerns are taken seriously in the production and consumption process taking place globally. ${ }^{96}$ To achieve the goal of addressing global environmental challenges such as climate change by promoting global reach of the EU law, the EU should first notice potential affected trade partners through either WTO Trade Policy Review Body (TPRB) or bilateral negotiation before the enactment of particular product environmental regulation. When the proposed rules go into effect, the EU should then provide technical and financial assistance to some developing countries intending to export industrial products to the EU market in order for them to comply with the EU environmental standards. The EU Partnership Instruments (PI) has initiated several coordinated programs to assist partner countries in complying with the EU regulatory requirements concerning climate change, energy, and circular economy. ${ }^{97}$ For instance, the EU has initiated the EU-Brazil and EU-Mexico programs for low-carbon business actions. PI also supports EU's initiatives in working closely with India in terms of water partnership, ICT product standardization, and clean energy. ${ }^{98}$

Taiwan is willing to cooperate with the EU for sustainable production and consumption of ICT products. The enhancement of the bilateral economic partnership between Taiwan and the EU shall start with the establishment of EU- 
Taiwan Policy Support Facilities, providing information exchange and technical assistance programs supported by the PI. In practice, this article suggests that technical task forces aiming at assisting with compliance with the latest legal development of EU product-based environmental regulation should be established and funded by both the EU and Taiwanese government in order to facilitate practical and constructional discussion among all stakeholders.

\section{REFERENCES}

1. J. Scott, Extraterritoriality and Territorial Extension of EU Law, 62 Am. J. InT'L L. 90 (2014).

2. B. Cooreman, Global Environmental Protection through Trade: A Systematic Approach to Extraterritoriality 8-9 (2017). See also A. Bradford, The Brussel Effects, 107 Nw. U. L. Rev. 2-3 \& 64-5 (2012).

3. From a trade perspective, the US had filed the complaint to the WTO challenging the EU's ban on hormone beef products entering into the EU market. See Appellate Body Report, EC Measures Concerning Meat and Meat Products (Hormones), WTO Doc. WT/ DS26/AB/R, WT/DS48/AB/R (adopted Feb. 13, 1998); The US also challenges the EU's strict premarket approval regulation and procedure concerning the growing of genetically modified crops and the sale of GM foods. See Panel Report, European Communities Measures Affecting the Approval and Marketing of Biotech Products, WTO Doc. WT/ DS291/R, WT/DS292/R, WT/DS293/R (adopted Sept. 29, 2006).

4. The taking of marine mammals incidental to commercial fishing operation is regulated under the Marine Mammal Protection Act (16 U.S.C. $\S$ 1361-1407). See 16 U.S.C. § 1387 (1972).

5. Malaysia, India, Pakistan and Thailand jointly filed a complaint against US's unilateral trade-restrictive measures against their shrimp products for not adopting new capture and harvest shrimp technology ensuring the escape of sea turtles at the WTO DSU. After further review, the Panel ruled that the US was justified under the exception of the GATT Article XX (g) as long as the provision of technical and financial assistance to all Member States does not act in discriminated fashion. See Panel Report, United States-Restrictions on Imports of Tuna, WTO Doc. WT/DS21/R-39S/155 (adopted Sept. 3, 1991).

6. Report from the Commission to the Parliament and the Council on Trade and Investment Barriers, at 7-8, COM (2008), available at https://trade.ec.europa.eu/doclib/docs/2019/ june/tradoc_157929.pdf. See also Scott, supra note 1, at 125.

7. For example, Clean Development Mechanism (CDM) and emission trading scheme 
adopted by the EU law have also to be endorsed in international climate change convention. The EU's Directive on electronic and electrical waste has influenced developments in the Basel Convention concerning the technical guidance of transboundary movement of e-waste globally. See P. Hagen, Product-based Environmental Regulations: Europe Sets the Pace, 6:3 Sustainable Dev. L. \& Pol'y 63-4 (2006).

8. Cooreman supra note 1; Scott, supra note 1, at 91.

9. The EU Timber regulation has enormous economic impacts to Vietnam, Indonesia, and Malaysia because due diligence checks have been imposed to timber products traders assuring their products were not from illegal harvesting of timbers. See H. Speechly \& F. van Helden, Forest governance in Southeast Asia, in Moving Forward with Forest Governance 101-2 (G. Broekhoven et al. eds., 2012). The EU IUU regulation has resulted in great impacts to Thailand due to its large amount exports of fishery products to the EU market. Thailand, through negotiation, agreed to seek for cooperation with EU in combating IUU fishing since 2019. See European Commission, Questions and Answers-Illegal, Unreported and Unregulated (IUU) fishing in general and in Thailand (Jan. 8, 2019), available at https://ec.europa.eu/commission/presscorner/detail/en/ MEMO_19_201.

10. K. Mfodwo et al., The European Council Regulation on Illegal, Unreported and Unregulated Fishing: An International Fisheries Law Perspective, 25 InT'L J. MARINE \& Coastal L. 6 (2010).

11. For details, see Executive Summary: Improving performance in the fight against illegal, unreported and unregulated (IUU) fishing - Recommendations for improving the EU IUU Regulation Catch Certificate (CC) Scheme, IUU WATCH (July 2016), available at http://www.iuuwatch.eu/wp-content/uploads/2016/07/IUU_Exec_summ_21July_rg_ hi.pdf.

12. Council Regulation (EC) No. 1005/2008 of Sept. 29, 2008, Establishing a Community system to prevent, deter and eliminate illegal, unreported and unregulated fishing, 2008 O.J. (L 286).

13. Commission adopts list of vessels engaged in IUU. See, Commission implementing Regulation (EU) No. 672/2013 of July 15, 2013 amending Regulation (EU) No. 468/2010 establishing the EU list of vessels engaged in illegal, unreported and unregulated fishing, 2013 O.J. (L 193/6).

14. Commission Regulation 1010/2009, 2009 O.J. (L 280), arts. 9 \& 16.

15. Excluding non-sustainability sourced fish from the EU market (Reg. 1026/2012; EU 2012b). See Commission Regulation No. 1026/2012 of the European Parliament and of the Council of Oct. 25, 2012 on certain measures for the purpose of the conservation of fish stocks in relation to countries allowing non-sustainable fishing 2012 O.J. (L 316) 34.

16. Commission Regulation (EU) No. 995/2010 of the European Parliament and of the Council of October 20, 2010 laying down the obligations of operators who place timber 
and timber products on the market, 2010 O.J. (L 295) 23.

17. Case C-366/10, Air Trans. Assoc. of America v. Sec'y of State for Energy and Climate Change, ECLI:EU:C:2011:864 (Dec. 21, 2011).

18. ICAO, Resolution A39-3: Consolidated statement of continuing ICAO policies and practices related to environmental protection-Global Market-based Measure (MBM) scheme, ICAO Doc. Assembly Res. A39-3 (Oct. 7, 2016).

19. Directive 2008/101/EC, of The European Parliament of the Council of November 19, 2008 amending Directive 2003/87/EC so as to include aviation activities in the scheme for greenhouse gas emission allowance trading within the Community, 2009 O.J. (L 8) 3.

20. Id.

21. J. Leggett et al., Aviation and the European Union's Emission Trading Scheme (2012), at 20, CRS Report (R42392), available at https://www.everycrsreport.com/files/2012061_ R42392_66a87164c680ed036af2b9261090d8a8da63ddc0.pdf.

22. Case C-366/10, supra note 17.

23. Id. at 129. See also J. Leggett et al, supra note 21, at 23-24.

24. See China Airlines Introduces ECO TRAVEL Carbon Offsetting, China Airline Press Release (Nov. 20, 2018), available at https://www.china-airlines.com/nl/en/discover/ news/press-release/20181120; EVA Air, Greenhouse Gas Management, available at http://www.evacsr.com/pages/en-us/ch4/gas-management.aspx.

25. Scott, supra note 1, at 124-5.

26. M. Buenger, The EU's ETS and Global Aviation: Why "Local Rules” Still Matter and May Matter Even More in The Future, 41 Denv. J. Int'L L. \& Pol'y 448-9 (2013).

27. Regulation (EC) No. 1907/2006, of the European Parliament and of the Council of December 18, 2006, concerning the Registration, Evaluation, Authorization and Restriction of Chemicals (REACH), establishing a European Chemicals Agency, 2007 O.J. (L 396) 1 , at 3 [REACH Regulation].

28. European Chemicals Agency (ECHA), Understanding REACH, available at https://echa. europa.eu/regulations/reach/understanding-reach.

29. REACH Regulation, art. 6.

30. There are two categories of exemptions: substances out of the scope of REACH and substances exempt under specific articles of REACH (e.g., substances used for research purposes or substance listed in Article 2 and from annex V).

31. REACH Regulation, art. 40.

32. Id. art. 46.

33. The substances subject to authorization process are listed under the Annex XIV of the REACH Regulation.

34. Id. art. 64.

35. Id.

36. Id. art. 68 . 
37. Hagen, supra note 7, at 64-5.

38. ChemSafetyPRO, Differences between Taiwan TCSCA and EU REACH (Nov. 11, 2019), available at https:/www.chemsafetypro.com/Topics/Taiwan/Differences_between Taiwan_TCSCA_and_EU_REACH_Regulation.html.

39. L. Kogan, Exporting Precaution: How Europe's Risk-Free Regulatory Agenda Threatens American Free Enterprise (2005), available at http://www.wlf.org/upload/ 110405MONOKogan.pdf. See also A. Pouillot et al., REACH: Impact on the US Cosmetics Industry? 8:1 J. Cosmetic Dermatology 5-6 (2009).

40. Directive (EU) 2017/2102 of the European Parliament and of the Council of November 15, 2017, amending Directive 2011/65/EU on the restriction of the use of certain hazardous substances in electrical and electronic equipment, 2017 O.J. (L 305) 8.

41. Taiwan Ministry of Economic Affairs, Taiwan's Foreign Trade Status and Policies 11 (July 24, 2019), available at https://www.trade.gov.tw/Pages/Detail.aspx?nodeID= $4023 \&$ pid $=675336$.

42. Taiwan Watch \& Clock Industrial Association, Latest Directives on the 6 Items Banned by EU WEEE and RoHS, available at http://www.twciatwn.org.tw/twciatwn_eng/ Latest\%20Directives.html.

43. Regulation (EC) No. 66/2010 of the European Parliament and of the Council of November 25, 2009, on the EU Ecolabel, 2010 O.J. (L 27), at 1.

44. EU Commission, Facts and Figures - Figures of March 2020 Show that the Number of EU Ecolabel Products Keeps Growing in The Majority of Product Groups (March 2020), available at $\mathrm{https}$ ://ec.europa.eu/environment/ecolabel/facts-and-figures.html.

45. S. Tranchard, New Version of ISO 14024 on Ecolabelling Just Published, ISO News, Mar. 9, 2018, available at https://www.iso.org/news/ref2273.html.

46. EU Commission, Ecolabel and Green Public Procurement, available at https://ec.europa. eu/environment/ecolabel/ecolabel-and-green-public-procurement.html. See also Ç. Gökirmakli et al., Behaviours of consumers on EU Eco-label: a case study for Romanian consumers. 23:3 Bulg. J. Agric. ScI. 512-6 (2017).

47. Directive 2009/125/EC of The European Parliament and of The Council of 21 October 2009 establishing a framework for the setting of ecodesign requirements for energyrelated products, Official J. E.U. L285/10 (Oct. 21, 2009), available at https://eur-lex. europa.eu/legal-content/EN/TXT/HTML/?uri=CELEX:32009L0125\&from=EN.

48. The Council of July 6, 2005 establishing a framework for the setting of eco-design requirements for energy-using products and amending Council Directive 92/42/EEC and Directives 96/57/EC and 2000/55/EC of the European Parliament and the Council, 2005 O.J. (L 191) 29 [Directive 2005/32/EC].

49. Id. art.3.

50. EFCTC, Eco-design of Energy-Using Products, available at https://www.fluorocarbons. org/eup-eco-design-energy-using-products. 
51. Directive 2005/32/EC, art.5; Directive 2009/28/EC of The Council of April 23, 2009 on the promotion of the use of energy from renewable sources and amending and subsequently repealing Directives 2001/77/EC and 2003/30/EC, 2009 O.J. (L 140) 16, art. 15 [EU 2009c].

52. Directive 2005/32/EC, arts. 3 \& 4; EU 2009c, art. 15(2)(b).

53. Directive 2005/32/EC, art.1.

54. Id. pmbl. 12.

55. Directive 2002/96/EC of the Council of January 27, 2003 on Waste Electrical and Electronic Equipment (WEEE), 2003 O.J. (L 37) 24 [WEEE Directive].

56. Directive 2002/95/EC of the Council of January 27, 2003 on the Restriction of the Use of Certain Hazardous Substances in Electrical and Electronic Equipment, 2003 O.J. (L 37) 19 [RoHS Directive].

57. WEEE Directive, arts. $12 \& 20$.

58. Hagen, supra note 37 , at $64-5$.

59. Directive 2002/96/EC of the Council of 27 January 2003 on waste electrical and electronic equipment, Article 5.2.(c) states that "distributors provide for the collection, at retail shops with sales areas relating to EEE of at least $400 \mathrm{~m} 2$, or in their immediate proximity, of very small WEEE (no external dimension more than $25 \mathrm{~cm}$ ) free of charge to end-users and with no obligation to buy EEE of an equivalent type, unless an assessment shows that alternative existing collection schemes are likely to be at least as effective, ..." WEEE Directive, art. 5.2(c).

60. Id.

61. Id.

62. Id. art. 7.

63. Id. art. 4.

64. Directive (EU) 2018/851 of the Council of May 30, 2018 amending Directive 2008/98/ EC on waste, 2018 O.J. (L 150) 109.

65. Id. art. 9.2.

66. Id. art. 8.a.

67. Id. art. 8.a(c).

68. A. Ibitz, Assessing Taiwan's Endeavors towards a Circular Economy: The Electronics Sector, 18 Asia Eur. J. (2020), available at https://link.springer.com/article/10.1007/ s10308-019-00568-w.

69. European Commission, European Union, Trade in goods with Taiwan (2020), available at https://webgate.ec.europa.eu/isdb_results/factsheets/country/details_taiwan_en.pdf.

70. See European Economic and Trade Office in Taiwan, Relations with the EU-Taiwan and the EU (May 17, 2016), available at https://eeas.europa.eu/delegations/taiwan_en/2000/ Taiwan\%20and\%20the \%20EU.

71. International Trade Centre, Market Analysis Tools Portal-Trade Map, available at http:// 
www.intracen.org/marketanalysis.

72. In 2017, FDI from the EU to Taiwan amounted to Euro 44.67bn, which contributes to $43 \%$ of all FDI stock from foreign countries. See European Economic and Trade Office, EU-Taiwan Relations 2018 (2018), available at https://eeas.europa.eu/sites/eeas/ files/2018_eu-taiwan_relations_en.pdf.

73. Hagen, supra note 37, at 9.

74. Scott, supra note 1, at 116-8.

75. For details on Taiwan's transplantation of legislation from an advance economist for an emergency of international society, see Jiunn-Rong Yeh \& Chun-Yuan Lin, The Paris Agreement and the Transformation of Global Climate Law: Taiwan's Perspective, 13 NTU. L. REv. 169-71 (2018).

76. R. Basedow, The US-China trade war: Risks and opportunities for the EU and the United Kingdom, LSE EUROPP Blog (Oct. 17, 2019), available at https://blogs.lse.ac.uk/ europpblog/2019/10/17/the-us-china-trade-war-risks-and-opportunities-for-the-eu-andthe-united-kingdom.

77. Taiwan Ministry of Economic Affair, Trade Statics - Value of ROC Import and Export Value by Country, available at https://cus93.trade.gov.tw/FSCE010F/FSCE010F.

78. Taiwan Ministry of Economic Affair, Trade Static-Value of ROC Import and Export Value by Product 2019, available at https://cus93.trade.gov.tw/FSCE020F/FSCE020F.

79. Stephen Su, Pitfalls and Opportunities for Taiwan from the Trade War-As Protectionism Spreads, Flexibility Becomes a Matter of Survival, TAIWAN BANKER, available at http:// service.tabf.org.tw/TTB/Article/Detail?aID=193.

80. Compliance \& Risks, Taiwan Increases E-waste Fee (May 20, 2019), available at http:// blog.complianceandrisks.com/news-resources/taiwan-increases-fee-rate-for-recyclingclearance-and-disposal-of-weee.

81. Chemical Watch, Taiwan issues voluntary RoHS guidelines (Aug. 24, 2013), available at https://chemicalwatch.com/16161/taiwan-issues-voluntary-rohs-guidelines.

82. Supra note 38.

83. For details on TEPA's legal proposal that is rooted from the underlining policy considerations incorporated in EU Waste Framework Directive, see Hsing-Hao Wu, Legal Development in Sustainable Solid Waste Management Law and Policy in Taiwan Lessons from Comparative Analysis Between EU and U.S., 6 NTU L. REv. 461-4 (2011).

84. Id. at 476-7.

85. Ming-Chien Su, Taiwan's Circular Economy: A New Era for Waste Management, TAIwAN Insight, Jan. 31, 2018, available at https://taiwaninsight.org/2018/01/31/taiwanscircular-economy-a-new-era-for-waste-management.

86. ChemSafetyPRO, Comply with First Taiwan TCSCA Phase I Registration Deadline: Challenges and Compliance Tips (Nov. 11, 2019), available at https://www.chemsafetypro. com/Topics/Taiwan/Taiwan_TCSCA_deadline_challenges_and_tips.html. 
87. ChemSafetyPRO, Introduction to Taiwan RoHS (Nov. 11, 2019), available at https:// www.chemsafetypro.com/Topics/Taiwan/Taiwan_RoHS_regulation_CNS_15663.html.

88. China Airline, China Airline Voluntary Greenhouse Gas Emission Reduction Statement (Oct. 2014), available at https://www.china-airlines.com/nl/en/discover/news/pressrelease/20181120; EVA Air, Greenhouse Gas Management, available at http://www. evacsr.com/pages/en-us/ch4/gas-management.aspx.

89. Shu-fen Wang \& Frances Huang, Airfares between Taiwan, Europe to rise on carbon trade scheme, Focus TAIWAN, May 11, 2011, available at https:/focustaiwan.tw/business/ 201111050027.

90. European Commission, Reducing emissions from aviation: Global Scheme to Offset Emissions, available at https://ec.europa.eu/clima/policies/transport/aviation_en.

91. EVA Air, Greenhouse Gas Management - Common Goal of Carbon Reduction, available at http://www.evacsr.com/pages/en-us/ch4/gas-management.aspxt.

92. Ming-Kuei Chien \& Li-Hsing Shih, Relationship between management practice and organisation performance under European Union directives such as RoHS: A case-study of the electrical and electronic industry in Taiwan, 1 Afr. J. Environ. Sci. \& Tech. 39-40 (2007).

93. Chen-Lung Yang \& Chwen Sheu, The Effects of Environmental Regulations on Green Supply Chains, 5:26 Afr. J. Bus. Mgmt. 10611-2 (2011).

94. EU REACH Directive (EC 1907/2006); WEEE Directive (2012/19/EU); RoHS directive (2011/65/EU), and EU Aviation Directive (2008/101/EC).

95. A. Dechezleprêtre \& Misato Sato, The Impacts of Environmental Regulations on Competitiveness, 11:2 Rev. EnvtL. Econ. \& Pol'y 197-200 (2017).

96. Professor Bradford argues that the EU has both regulatory capacity and preference of strict rule regulatory propensity to operate global regulatory powers and even to supply global standards. See Bradford, supra note 2, at 10-8.

97. Regulation (EU) No. 234/2014 of the Council of Mar. 11, 2014 establishing a Partnership Instrument for cooperation with third countries, 2014 O.J. (L 77) 77. This EU Partnership Instrument provides policy facilities and capacity building actions programs in terms of achieving the EU's global strategy. See European Commission, The Partnership Instrument, advancing the EU's core interests, available at https://ec.europa.eu/fpi/whatwe-do/partnership-instrument-advancing-eus-core-interests_en.

98. EU Commission, State of Play Partnership Instrument 2014-2019, available at https:// www.docdroid.net/9SK55us/pi-state-of-play-2014-2019-april-update-pptx. 